\title{
PAMIĄTKI PO HENRYKU SIENKIEWICZU W ZBIORACH BIBLIOTEKI NAUKOWEJ PAU I PAN W KRAKOWIE
}

W 2016 r. mija 170. rocznica urodzin i 100. rocznica śmierci znakomitego polskiego pisarza, laureata nagrody Nobla Henryka Sienkiewicza. Z tej okazji Senat Rzeczypospolitej Polskiej na posiedzeniu 18 grudnia 2015 r. podjął uchwałę w sprawie ogłoszenia roku 2016 Rokiem Henryka Sienkiewicza, przyjętą większością głosów przy jednym wstrzymującym się. Napisano w niej, że setna rocznica śmierci pisarza, który poprzez swoją twórczość literacką i publicystyczną oraz działalność społeczną budził świadomość narodową, uczył dumy z polskości, umiłowania ojczyzny i zdolności do poświęceń, jest okazją do oddania mu hołdu. Zdaniem Senatu, obchody tej rocznicy powinny przyczynić się również do popularyzacji twórczości Sienkiewicza, a zwłaszcza idei zawartych w jego dziełach - patriotyzmu i przywiązania do tradycyjnych wartości ${ }^{1}$.

Działając zgodnie z uchwałą Senatu RP, by przyczynić się do popularyzacji twórczości Sienkiewicza, wykorzystujemy setną rocznicę śmierci pisarza do zaprezentowania zbiorów z nim związanych, znajdujących się w Bibliotece Naukowej PAU i PAN, a także przypomnienia jego związków z Akademią Umiejętności w Krakowie.

Henryk Sienkiewicz urodził się 5 maja 1846 r. we wsi Wola Okrzejska w powiecie łukowskim. Jego ojciec, Józef, niezamożny właściciel ziemski, pieczętujący się herbem Okszyk, wywodził się ze spolszczonego i nobilitowanego w XVIII wieku rodu Tatarów litewskich. Matka, Stefania, pochodziła ze starej i majętnej rodziny podlaskiej Cieciszowskich. Henryk Sienkiewicz kształcił się w gimnazjum w Warszawie, następnie studiował w Szkole Głównej Warszawskiej, początkowo na wydziale lekarskim, potem przeniósł się na studia prawnicze. W tym czasie rozpoczął działalność literacką. Stopniowo zdobywał uznanie, publikując swe utwory w warszawskich gazetach i czasopismach. Wiele podróżował - podróż do Stanów

\footnotetext{
${ }^{1}$ Źródła internetowe.
} 
Zjednoczonych zaowocowała m. in. Listami z podróży do Ameryki, a z innego dalekiego wyjazdu opublikował Listy z Afryki. Jego kolejno wydawane powieści budziły zainteresowanie, były oczekiwane i na bieżąco komentowane. Sienkiewicz stawał się słynnym pisarzem, społecznym działaczem i uznanym autorytetem. Zwieńczeniem jego sukcesów stała się literacka nagroda Nobla, wręczona 10 grudnia 1905 r. w Sztokholmie. Henryk Sienkiewicz zmarł 15 listopada 1916 r. w Vevey pod Lozanną. Pogrzeb odbył się 22 listopada w Vevey przy udziale szwajcarskich władz i przedstawicieli dyplomatycznych. Papież Benedykt XV wystosował uroczysty adres, a król angielski Jerzy V przysłał wieniec. W kraju i za granicą odbywały się nabożeństwa i akademie żałobne, o śmierci pisarza wiele pisała prasa. W wolnej Polsce, w 1924 r. prochy pisarza uroczyście sprowadzono do kraju i złożono je w podziemiach katedry św. Jana w Warszawie, tuż obok sarkofagu prezydenta Gabriela Narutowicza ${ }^{2}$.

Dzieła Henryka Sienkiewicza doczekały się wielu adaptacji filmowych, w polskich miastach stoją jego liczne pomniki, szkoły noszą jego imię. Powstały też muzea - w Oblęgorku, Woli Okrzejskiej i Poznaniu. Rok 1966 był ogłoszony Rokiem Sienkiewiczowskim, więc obecna inicjatywa Senatu RP nie jest pierwszym tego rodzaju wezwaniem do ogólnopolskiego uczczenia pamięci słynnego pisarza ${ }^{3}$.

Biografia i twórczość Henryka Sienkiewicza zostały już dokładnie opracowane i opisane ${ }^{4}$. Warto jednak wspomnieć, że w zbiorach rękopiśmiennych Biblioteki PAU i PAN w Krakowie znajdują się materiały bio-bibliograficzne dotyczące tego pisarza zgromadzone przez Michała Frąckiewicza, przygotowującego słownik biograficzny ${ }^{5}$, jak również mające podobny charakter zbiory historyka literatury Ludwika Kamykowskiego ${ }^{6}$.

Cenne źródło do życia i twórczości znakomitych ludzi, m.in. wielkich pisarzy stanowią listy. Dorobek epistolograficzny Henryka Sienkiewicza, według szacunkowych obliczeń, wynosi ponad 15000 listów. W czasie swej największej popularności pisarz otrzymywał po około 400 listów miesięcznie i w większości na nie odpisywał. Spędzając długie okresy czasu samotnie w różnych uzdrowiskach, brak rozmów z bliskimi zastępował pisaniem listów, czasem po kilka dziennie. Był jednym z najpłodniejszych epistolografów polskich, podobnie jak Józef Ignacy Kraszewski, Zygmunt Krasiński czy Eliza Orzeszkowa. Wskutek zaniedbań, a zwłaszcza zniszczeń drugiej wojny światowej, zachowała się tylko niewielka część listów pisarza ${ }^{7}$.

${ }^{2}$ H. Markiewicz, Sienkiewicz Henryk, „Polski Słownik Biograficzny”, Warszawa-Kraków 1996-1997, t. 37, s. 203-216.

3 Tamże, s. 214.

${ }^{4}$ Zob. np. J. Krzyżanowski, Henryk Sienkiewicz, Warszawa 1986; J. Kulczycka-Saloni, Henryk Sienkiewicz, Warszawa 1966; B. Kaniewska, Henryk Sienkiewicz, Poznań 1999; M. Korniłowiczowna, Henryk Sienkiewicz, Warszawa 2005; H. Markiewicz, Sienkiewicz Henryk..., i in.

${ }^{5}$ Bibl. Nauk. PAU i PAN, rkps 2159, t. 17, k. 147-150.

${ }^{6}$ Tamże, rkps 6343, k. 6v-7.

7 J. Krzyżanowski, Listy Henryka Sienkiewicza [w]: Henryk Sienkiewicz. Listy, oprac. i przypisy M. Bokszczanin, Warszawa 1977, t. 1, cz. 1, s. 5-7. 
W pięciotomowym wydawnictwie obejmującym zachowane listy Henryka Sienkiewicza, opublikowane zostały też jego listy, których oryginały przechowywane są w Bibliotece Naukowej PAU i PAN ${ }^{8}$. Największa liczba zachowanych listów Sienkiewicza adresowana była do Stanisława Tomkowicza, krakowskiego historyka sztuki, członka Akademii Umiejętności i współredaktora „Czasu”. Wśród korespondencji Tomkowicza znajduje się 35 listów z lat 1889-1896, ponadto jeden telegram ${ }^{9}$.

Przechowywany jest także, datowany na ok. 1 lutego 1899 r., list Sienkiewicza z Warszawy do znanego poety i powieściopisarza okresu Młodej Polski Kazimierza Przerwy-Tetmajera, zachowany $\mathrm{w}$ zbiorze jego korespondencj ${ }^{10}$. W druku podano również dwa listy Sienkiewicza do profesora Uniwersytetu Jagiellońskiego Bolesława Ulanowskiego, przechowywane w jego korespondencji, wysłane z Krakowa 24 sierpnia i 2 września 1908 r. ${ }^{11}$ oraz jeden list do ziemianina Karola Bernarda Załuskiego, wysłany z Bordighery 4 kwietnia 1901 r. ${ }^{12}$ Jeden z listów Sienkiewicza w zbiorach Biblioteki Naukowej PAU i PAN, z 28 października 1895 r., z Warszawy, skierowany jest do Edwarda Janczewskiego ${ }^{13}$ - został on, jak powyższe, opublikowany ${ }^{14}$. Należy wspomnieć o jeszcze jednej przesyłce listowej Sienkiewicza skierowanej do Janczewskiego. Chodzi o odpis tekstu (dokonany nieznaną ręką) „Odpowiedź Sienkiewicza do dziennika 'Gegenwart' o Bismarcku” ${ }^{15}$. Należy zauważyć, iż Sienkiewicz zarówno w prasie krajowej, jak i zagranicznej występował jako reprezentant opinii publicznej przeciw antypolskiej polityce Prus. Na łamach berlińskiego tygodnika „Der Gegenwart” zamieścił swą odpowiedź na ankietę ogłoszoną przez pismo ${ }^{16}$.

Poniżej znajduje się krótki dopisek Sienkiewicza. Ponieważ nie był nigdzie wykorzystany drukiem, pozwólmy sobie na jego zacytowanie:

Ps. Redakcyja Gegenwart nie tylko skwapliwie umieściła ten list, ale w osobnym dopisku wyróżnia go między innemi i nazywa znakomitym.

Kochany Edwardzie. Powiedz w Redakcyi, że oryginał posyłam dlatego, by list po polsku dany był tak, jak go napisałem ${ }^{17}$. t. $1-5$.

${ }^{8}$ Henryk Sienkiewicz. Listy, oprac. i przypisy M. Bokszczanin, Warszawa 1977-2009,

9 Bibl. Nauk. PAU i PAN, rkps 1993, k. 105-170. Druk: Henryk Sienkiewicz. Listy..., t. 5, cz. 1, s. $558-589$.

${ }^{10}$ Tamże, rkps 4662 t. 2, k. 19-20. Druk: Henryk Sienkiewicz. Listy..., t. 5, cz. 1, s. 550-551.

${ }_{11}$ Bibl. Nauk. PAU i PAN, rkps 2402, t. 3, k. 19-21. Druk: Henryk Sienkiewicz. Listy..., t. 5, cz. 2, s. 173-175.

${ }_{12}$ Bibl. Nauk. PAU i PAN, rkps 7987, k. 8-9. Druk: Henryk Sienkiewicz. Listy..., t. 5, cz. 2, s. $570-571$.

${ }_{13}$ Bibl. Nauk. PAU i PAN, rkps 2001, k. 64.

${ }^{14}$ Warszawa 1996, t. 2, cz. 3, s. 167.

${ }^{15}$ Bibl. Nauk. PAU i PAN, rkps 2001, k. 66-69v.

${ }^{16}$ H. Markiewicz, Sienkiewicz Henryk..., s. 210.

${ }_{17}$ Bibl. Nauk. PAU i PAN, rkps 2001, k. 69v. 
Kolejny z autografów listu Henryka Sienkiewicza ma formę ołówkowego brulionu, zachowanego w złym stanie z powodu urwanego prawego brzegu. Skierowany był do rzeźbiarza Teodora Rygiera, a wysłany z Krakowa ok. 25 listopada 1892 r. Sienkiewicz należał początkowo do Komitetu Budowy Pomnika Mickiewicza, z czasem się z niego wycofał. Projekt pomnika autorstwa Rygiera został skierowany do realizacji. Brulion listu zachował się w korespondencji Władysława Leopolda Jaworskiego, dotyczącej budowy pomnika Mickiewicza w Krakowie $^{18}$.

Omawiając listy Henryka Sienkiewicza przechowywane w zbiorach Biblioteki Naukowej PAU i PAN, należy wspomnieć o jego listach do Polskiego Akademickiego Stowarzyszenia „Ognisko” w Wiedniu. Zachowały się dwa listy, a mianowicie z 18 stycznia 1903 r. z Krakowa ${ }^{19}$ oraz z 10 kwietnia 1908 r. wysłany z Warszawy ${ }^{20}$. Stowarzyszenie „Ognisko” nadało Sienkiewiczowi w 1901 r. tytuł członka honorowego, w uznaniu jego zasług jako pisarza i jako dowód hołdu polskiej młodzieży w Wiedniu ${ }^{21}$. Z działalnością Sienkiewicza na niwie publicznej wiąże się też niedatowany list do Koła Polskiego w Wiedniu. W tym przypadku autorstwo Sienkiewicza traktować należy ze sceptycyzmem. Jest to bowiem odpis, z adnotacją Zygmunta Lasockiego; „Rzekomo list Sienkiewicza” 22. Można zaznaczyć, iż jedyny nie budzący wątpliwości list pisarza z 11 lutego 1901 r. do Koła Polskiego w Wiedniu opublikowany jest w zbiorze listów Sienkiewicza ${ }^{23}$. Zachowany też został w papierach Antoniego Józefa i Michała Rolle, list Henryka Sienkiewicza z 2 kwietnia 1908 r. do nieznanego z nazwiska redaktora Księgi pamiatkowej Adamowi Krechowieckiemu, wydanej we Lwowie w 1908 r. Pisarz zapowiadała w nim rychłe przesłanie tekstu do Księgi, który ma już na ukończeniu ${ }^{24}$. Chodziło tu o nowelę opartą na motywach antycznych, pt. Wesele ${ }^{25}$.

Na marginesie można dodać, że pod listem działacza społeczno-oświatowego i adwokata Antoniego Osuchowskiego do Teodora Wierzbowskiego z 14 grudnia 1901 r., z zaproszeniem na naradę $\mathrm{w}$ sprawie organizowanej przez Towarzystwo Naukowe Warszawskie wystawy, znajduje się również podpis Henryka Sienkiewicza ${ }^{26}$. Podpis Sienkiewicza znajduje się również pod pismem Komitetu Generalnego Pomocy dla ofiar wojny w Polsce (w Vevey), z 29 maja 1915 r. Pisarz

${ }_{18}$ Tamże, rkps 3154, k. 19. Druk: Henryk Sienkiewicz. Listy..., Warszawa 2007, t. 3, cz. 3, s. $380-381$.

19 Bibl. Nauk. PAU i PAN, rkps 2442, k. 25, k. 14-15. Druk: Henryk Sienkiewicz. Listy..., t. 5, cz. 3, s. 238.

${ }^{20}$ Bibl. Nauk. PAU i PAN, rkps 3894, k. 7. Druk: Henryk Sienkiewicz. Listy..., t. 5, cz. 3, s. 239 .

${ }^{21}$ Bibl. Nauk. PAU i PAN, rkps 2442, k. 25, druk.

22 Tamże, rkps 4079, k. 120-121.

${ }^{23}$ Henryk Sienkiewicz. Listy..., t. 5, cz. 3, s. 160.

${ }^{24}$ Bibl. Nauk. PAU i PAU, 8969, k. 18.

${ }^{25}$ Henryk Sienkiewicz. Listy..., t. 3, cz. 1, s. 306.

${ }^{26}$ Bibl. Nauk. PAU i PAN, rkps 1881, t. 24 k. 141. 
w piśmie dziękczynnym za dar pieniężny polskiej kolonii robotniczej w Corcelles, występuje jako „Le Président du Comitè Gènéral”27.

Dla porządku odnotować należy istnienie w zbiorach Biblioteki listu polskiego polityka i ekonomisty Leona Bilińskiego do Henryka Sienkiewicza, z 30 III 1916 r. List związany jest $\mathrm{z}$ zaangażowaniem pisarza w pomoc Polakom ofiarom wojny, prowadzoną w Szwajcarii. Niestety, list ten, znajdujący się w papierach Zygmunta Lasockiego to jedynie maszynopisowa kopia ${ }^{28}$.

Za cenną pamiątkę po Henryku Sienkiewiczu w zbiorach Biblioteki Naukowej PAU i PAN należy uznać autograf „Listów z Afryki”, sześciokartkowy rękopis oznaczony jako „XII”. Pochodzi z teki redakcyjnej „Czasu”, przekazany został przez historyka i konserwatora zabytków Stanisława Tomkowicza, członka Akademii Umiejętności. Listy z Afryki drukowane były w krakowskim „Czasie” w latach 1891-1892. Znaczenie tego dokumentu doceniono już przed wielu latu, bowiem został on poddany konserwacji i oprawiony przez Spółdzielnię „Starodruk” w 1956 r. $^{29}$ Natomiast w papierach historyka Kazimierza Lepszego znajduje się maszynopisowy odpis fragmentu „Listów z Afryki”, rozdział V, o oryginalnej paginacji: s. $1-9^{30}$.

Ciekawą pamiątkę związaną z Sienkiewiczem stanowią wspomnienia dr Felicji Kęszyckiej-Schnaydrowej pt. „Poznanie osobiste Henryka Sienkiewicza. Jego pogrzeb”. Ich autorka była studentką historii, sekretarką Patronatu Robotniczego i skarbniczką akademickiej Bratniej Pomocy w szwajcarskim Fryburgu. W latach 1915-1917 jeździła do Vevey na konferencje i po odbiór pieniędzy dla tych instytucji. Przyjmował ją mecenas Antoni Osuchowski, prezes Komisji Wykonawczej Komitetu Generalnego Pomocy Ofiarom Wojny w Polsce. Marzeniem ówczesnej studentki było osobiste spotkanie z Henrykiem Sienkiewiczem, co pewnego wrześniowego dnia 1915 r. dnia doszło do skutku. Pisarz był już wówczas bardzo słaby i schorowany, a jak napisała Felicja Kęszycka:

Był uroczy i tak bezpośredni, że wydawał się nam, że mówi z nami ukochany ojciec. Zasiadł na kanapce wśród nas 6-ciu młodych i wypytywał się troskliwie, z których stron Polski pochodzimy. Dowiedziawszy się, że wszyscy jesteśmy z Wielkopolski, powiedział: „Dzieci kochane, Polska po tej wojnie zmartwychwstanie i w waszych rękach spoczywają jej dalsze losy”.

Uczestniczyła też w pogrzebie pisarza w Vevey, wśród tłumu wzruszonych rodaków ${ }^{31}$.

Twórczość Henryka Sienkiewicza stawała się przedmiotem pogłębionych badań, a także inspiracją do różnego typu rozważań, chociażby nad postaciami historycznymi i literackimi występującymi na kartach jego książek. I tak, w spuściźnie literata

27 Tamże, rkps 10 333, nlb.

28 Tamże, rkps 4078, k. 25-28.

${ }^{29}$ Tamże, rkps 2474, k. 1-6.

30 Tamże, rkps 7688, t. 1, k. 170-174.

31 Tamże, rkps 10 412, nlb (rkps i mszp. z poprawkami). Druk: „Kultura” 1996, nr 10, s. 126 129. 
i publicysty katolickiego Józefa Mariana Święcickiego znajdują się rozważania nad postacią Leona Płoszowskiego z powieści Bez dogmatu, analiza literacka powieści, krytyczna charakterystyka postaci bohatera literackiego na tle współczesnej Sienkiewiczowi literatury ${ }^{32}$. Z kolei, w materiałach do rozpraw i artykułów Zygmunta Lasockiego przechowywane są notatki, wypisy o charakterze historycznym, służące analizie i pogłębieniu postaci Jana Skrzetuskiego z powieści Ogniem i mieczem ${ }^{33}$. W miscellaneach z papierów po Koźmianach znajduje się rękopiśmienne opracowanie Benedykta Filipowicza, a mianowicie przeróbka fragmentu wspomnianej powieści Ogniem i mieczem ${ }^{34}$. Można też zwrócić uwagę na rękopis krytycznego komentarza M. F. Urbańskiego („Ojcowica”) do wykładu publicznego Henryka Struvego pt. „O najwyższej zasadzie postępowania etycznego”, wygłoszonego 24 marca 1903 r. w Towarzystwie Osad Rolnych, a wydrukowanego w „Przeglądzie Filozoficznym". Urbański w swoim obszernym opracowaniu zatytułowanym „Sonata Sienkiewicza i etyka prof. H. Struvego”, poświęcił wiele uwagi sylwetce Henryka Sienkiewicza i jego literackiemu talentowi ${ }^{35}$. Na marginesie można dodać informację o przechowywanym w papierach Antoniego Kleczkowskiego maszynopisie opracowania Józefa Tretiaka „Goethe i Hakata” zainspirowanego Listem otwartym do JCM Wilhelma II króla pruskiego Henryka Sienkiewicza z 19 listopada 1906 r., opublikowanym w „Czasie” i „Kurierze Warszawskim”36.

Fotografie i inne wizerunki Henryka Sienkiewicza nie należą do rzadkości. Również i w zbiorach rękopiśmiennych Biblioteki PAU i PAN znajdujemy liczne podobizny pisarza. Warto nadmienić, iż pojedyncze zdjęcia znanych osobistości można było nabyć po przystępnej cenie w zakładzie fotograficznym. Tak zatem, ktoś udający się do fotografa nie mógł być pewien, czy jego podobizna nie znajdzie się w publicznym obiegu. Sławny pisarz prezentował się na fotografii swoim aktualnym czytelnikom końca XIX i początków XX wieku. Fotografia zyskiwała wymiar ponadczasowy, zatem osoba dająca się fotografować starała się zaprezentować jak najkorzystniej. Jak napisał Jerzy Kandziora: ,[...] fotografia pisarza jest jakby plotką o jego dziele. Sprowadza nieco na ziemię, choć przecież nie profanuje, a tylko wzniosłość uprzystępnia”. Henryk Sienkiewicz był wdzięcznym obiektem do fotografowania. Słynna aktorka Helena Modrzejewska twierdziła, iż pisarz twarz ma ładną, zaś warszawska prasa donosiła, że: „dysponuje urodą naznaczoną piętnem wysokiej rasowości" ${ }^{37}$.

Fotografia młodego pisarza, z profilu, znajduje się w spuściźnie po Janie Klimczyku $^{38}$. Ciekawa fotografia w sepii, również z czasów młodości, znajduje się wśród

32 Tamże, rkps 10 921, k. 45-57.

33 Tamże, rkps 4110, k. 1-68.

${ }^{34}$ Tamże, rkps 2063, k. 107-123.

${ }^{35}$ Tamże, rkps 12 051, k. 1-36.

${ }^{36}$ Tamże, rkps 6495, k. 86-94.

${ }^{37}$ J. Kandziora, Henryk Sienkiewicz na fotografii. Ze zbiorów Muzeum Literackiego Henryka Sienkiewicza w Poznaniu, Poznań 1884, nlb.

${ }^{38}$ Bibl. Nauk. PAU i PAN, rkps 3850, k. 5. 
papierów Bronisławy Rychter-Janowskiej ${ }^{39}$, a w zbiorach Kazimierza Lepszego, portret wykonany przez krakowskiego fotografa Stanisława Bizańskiego ${ }^{40}$. Henryk Sienkiewicz widnieje na fotografii zbiorowej z 1916 r., pomiędzy prawnikiem, publicystą i działaczem narodowym Antonim Osuchowskim a warszawskim lekarzem i społecznikiem Stanisławem Hassewiczem - zdjęcie to zachowało się w spuściźnie Jana Hulewicza ${ }^{41}$. Henryka Sienkiewicza znajdziemy również na fotografii zbiorowej współpracowników „Kuriera Warszawskiego”, z daru Jadwigi Podolskiej ${ }^{42}$. Ze zbiorów Zygmunta Lasockiego pochodzą dwa egzemplarze pocztówki z fotografią portretową pisarza, wykonaną przez warszawskiego fotografa Mariana Fuksa ${ }^{43}$. Z kolei z papierach ks. Jana Fijałka przechowywana jest kolorowa reprodukcja obrazu Tadeusza Korpala w formie pocztówki, przestawiająca Henryka Sienkiewicza ${ }^{44}$. $\mathrm{Na}$ marginesie warto zaznaczyć, iż Korpal wykonał szereg rozpowszechnianych jako pocztówki obrazów o tematyce z powieści Quo vadis. Zaznaczyć też należy, iż w zbiorach Biblioteki PAU i PAN przechowywane są nie tylko reprodukcje fotograficzne wizerunku Henryka Sienkiewicza. W spuściźnie Jacka Malczewskiego, wśród szkiców głów znajduje się także oryginalny portret Henryka Sienkiewicza ${ }^{45}$. Warto też wspomnieć, iż w Bibliotece Polskiej w Paryżu, agendzie Polskiej Akademii Umiejętności, współwłaściciela tej placówki, znajduje się miniaturowa akwarela (o wymiarach $76 \times 64 \mathrm{~cm}$, bez ramki: $65 \times 52 \mathrm{~cm}$ ), przedstawiająca Henryka Sienkiewicza, autorstwa dotychczas nieustalonego malarza ${ }^{46}$.

Henryk Sienkiewicz oprócz niezaprzeczalnego talentu literackiego, przejawiał też zdolności i zainteresowania rysownicze. Otóż w papierach Henryka Struvego znajdują się szkice pisarza, wykonane przezeń podczas posiedzenia Kasy im. Mianowskiego, 15 stycznia 1882 r. Jak można przypuszczać pisarz znudzony był toczącymi się obradami, zatem urozmaicał sobie czas rysując ołówkiem portret brodatego mężczyzny, a poniżej głowę młodzieńca z profilu, a także miecz z ozdobną rękojeścią ${ }^{47}$.

Fotografie Henryka Sienkiewicza i inne obiekty ikonograficzne z nim związane są udostępniane w sukcesywnie uzupełnianym katalogu internetowym PAUart. Projekt, rozpoczęty w 2014 r. ma za zadanie udostępnić szerokiemu gronu odbiorców
39 Tamże, rkps 10 540, k. 20.
${ }^{40}$ Tamże, rkps 7715, k. 14.
${ }^{41}$ Tamże, rkps 10373 , nlb.
42 Tamże, rkps 6545, nlb.
43 Tamże, rkps 4320, k. 9 i 10.
${ }^{44}$ Tamże, rkps 4716, t. 7, k. 72.
45 Tamże, rkps 4038, k. 29.
${ }^{46}$ Biblioteka Polska w Paryżu, Kolekcja Artystyczna, nr inw. II 146.
${ }^{47}$ Bibl. Nauk. PAU i PAN, rkps 3580, k. 36. Szkice autorstwa Sienkiewicza były edytowane w artykule Z. Jabłońskiego, Wystawa „,W stulecie założenia Akademii Umiejętności”. Kraków 2 maja- 10 czerwca 1973, „Rocznik Biblioteki PAN w Krakowie”, R. 19: 1973, il. 12. Zob. odbitki fotogra- ficzne (2 szt.) w fotografiach po Krystynie Stachowskiej, Bibl. Nauk. PAU i PAN, rkps 12 520, k. $37-38$. 
ikonograficzne zbiory artystyczne i naukowe przechowywane w Polskiej Akademii Umiejętności.

Można też zaznaczyć istnienie w zbiorach rękopiśmiennych, wśród korespondencji Teofila Lenartowicza, wizytówki Henryka Sienkiewicza. Jak widać popularność osoby pisarza była wielka i nie budząca wątpliwości, gdyż na wizytówce widnieje jedynie nazwisko: „Sienkiewicz” ${ }^{48}$. Zachowało się również wśród zaproszeń i zawiadomień ślubnych, zgromadzonych przez Józefa Weyssenhoffa, drukowane zawiadomienie o ślubie Henryka Sienkiewicza z panną Marią Wołodkowiczówną, córką Konstantego i Heleny z Drzewieckich Wołodkowiczów. Ślubu udzielił arcybiskup Albin Dunajewski w Krakowie, w Kaplicy Kardynała Księcia Biskupa Krakowskiego, dnia 11 listopada 1893 r. o godz. 11 rano ${ }^{49}$. Na marginesie można dodać, iż małżeństwo nie okazało się trwałe, gdyż żona rychło opuściła Sienkiewicza, a małżeństwo zostało unieważnione dyspensą Stolicy Apostolskiej.

Wspomnieć też należy o innym druku związanym z Henrykiem Sienkiewiczem przechowywanym wśród papierów Zygmunta Lasockiego, a mianowicie o wytwornym w formie zaproszeniu przez Komitet Uczczenia Pamięci Henryka Sienkiewicza w Pradze, 24 października 1924 r., o godz. 16, do Panteonu Muzeum Narodowego. W ten sposób naród czeski chciał uhonorować polskiego pisarza noblistę. Jak już wspomniano, właśnie w 1924 r. prochy pisarza uroczyście sprowadzono z Vevey w Szwajcarii do Polski ${ }^{50}$.

Wycinki prasowe znajdujące się w poszczególnych zbiorach i spuściznach trudno uznać za źródło pierwszorzędnej kategorii, aczkolwiek warto odnotować istnienie wycinków dotyczących - w tym przypadku - Henryka Sienkiewicza. I tak, w albumie Zofii i Ferdynanda Hoesików znajduje się wiersz Sienkiewicza zamieszczony w „Czasie”, pt. Pieśń litewskich borów, z uwagą, że jest to publikacja nieznanego wiersza twórcy ${ }^{51}$, natomiast wśród poezji zgromadzonej przez Ludwika Kamykowskiego zachował się wycinek z niezidentyfikowanej gazety zawierający wiersz Sienkiewicza, inspirowany poezją Horacjusza: Pochwały życia wiejskiego (Vitae Rustica e laudes) $^{52}$. W nurt badań nad korespondencją Henryka Sienkiewicza wpisuje się kolejny zachowany $\mathrm{w}$ materiałach bibliograficzno-historycznych Jana Fijałka wycinek prasowy, niewykluczone, że z „Czasu” - niedatowany list do Henryka Sienkiewicza od kilku mieszkańców Śląska (stróża kolejowego, ceglarza i brązownika), z podziękowaniem za jego pisarstwo niosące pociechę mieszkańcom ziemi śląskiej, gnębionym przez Niemców ${ }^{53}$. Również ks. Jan Fijałek do swoich zbiorów włączył wycinek z niezidentyfikowanej gazety z 11 maja 1907 r. - List uchodźców polskich do Sienkiewicza. Z okazji rocznicy uchwalenia Konstytucji 3 Maja w Duisburgu nad Renem odbył się wiec Związku Polaków w Niemczech,

${ }^{48}$ Bibl. Nauk. PAU i PAN, rkps 2028, t. 6, k. 268.

49 Tamże, rkps 7203, k. 101.

50 Tamże, rkps 4075, k. 41-42.

${ }^{51}$ Tamże, rkps 4381, k. 72.

52 Tamże, rkps 6406, k. 164v-165v.

${ }^{53}$ Tamże, rkps 4819, t. 2, k. 246. 
a na wniosek Józefa Sieradzkiego jednomyślnie uchwalono wysłanie listu do Sienkiewicza z podziękowaniem za jego apel wzywający Polaków w Królestwie Polskim do uczczenia rocznicy 3 Maja $^{54}$. Ciekawy jest wycinek prasowy z "Czasu” zawierający przedruk artykułu z „Gazety Polskiej” pt. Wizyta chłopa u Sienkiewicza. Chłopem tym był Wincenty Stec z Kobiernik koło Sandomierza. Jako wierny i zachwycony czytelnik książek Henryka Sienkiewicza, wybrał się do Warszawy, aby osobiście pisarzowi podziękować i złożyć dar - polski, pachnący chleb. Sienkiewicz przyjął go życzliwie, porozmawiał i podarował żelazną kulę - pamiątkę z Częstochowy oraz bilecik do księgarni Gebethnera i Wolfa, skąd Wincenty Stec otrzymał kilka egzemplarzy Krzyżaków ${ }^{55}$. W archiwum poety, prozaika i publicysty Witolda Zechentera znajdują się dwa wycinki z artykułami jego autorstwa. Jeden z nich to Je connais Sienkiewicz, wydrukowany w „Głosie Literackim”, w których Zechenter zrelacjonował swoją rozmowę z kilkoma różnymi cudzoziemcami, podczas której zorientował się, że spośród polskich pisarzy kojarzyli jedynie nazwisko Sienkiewicza poprzez lekturę Quo vadis ${ }^{56}$, zaś drugi - A Sienkiewicz wciąż górą, dotyczący przekładów dzieł polskich pisarzy na języki obce. Okazało się, że najczęściej tłumaczone były powieści Sienkiewicza, na czele z nagrodzoną Noblem Quo vadis ${ }^{57}$.

Pamiątki po Henryku Sienkiewiczu, przechowywane w rękopiśmiennych zbiorach Biblioteki, były eksponowane wśród innych cennych zbiorów na wystawie zorganizowanej dla uczczenia stulecia założenia Akademii Umiejętności, od 2 maja do 10 czerwca 1973 r. Eksponaty były udostępniane zwiedzającym w czterech salach na parterze pałacu Pod Krzysztoforami przy krakowskim Rynku Głównym. Spośród materiałów po Henryku Sienkiewiczu w zbiorach Biblioteki, udostępniono fragment autografu z 1891 r. ,Listów z Afryki”, z teki redakcyjnej „Czasu” pochodzącej z kolekcji Stanisława Tomkowicza, a znajdującego się zarówno wówczas, jak i obecnie pod sygnaturą 2474. Wyeksponowano również szkice ołówkowe Henryka Sienkiewicza rysowane w czasie posiedzenia Kasy im. Mianowskiego, 15 stycznia 1882 r., pochodzące z kolekcji Henryka Struvego (sygn. 3580). Spośród licznych wizerunków pisarza, udostępniono fotografię z około 1880 r. ${ }^{58}$

Mówiąc o związkach Henryka Sienkiewicza z Akademią Umiejętności, nie sposób nie wspomnieć o ustanowionej przez niego Fundacji im. śp. Marii z Szetkiewiczów Sienkiewiczowej. Maria była jego ukochaną żoną, a w czasie czteroletniego okresu trwania ich małżeństwa (1881-1885) rozpoczął się czas świetności pisarstwa Sienkiewicza. Śmierć żony, zmarłej w wieku 31 lat na gruźlicę, była dla pisarza wielkim ciosem. Trzy lata później, w 1888 r. postanowił uczcić jej pamięć tworząc Fundację im. śp. Marii z Szetkiewiczów Sienkiewiczowej. Bezpośrednią

54 Tamże, rkps 4816, k. 121.

55 Tamże, rkps 4855, k. 1654.

56 Tamże, rkps 10722, k. 33v.

57 Tamże, rkps 10729 , k. 40.

58 Z. Jabłoński, Wystawa „W stulecie założenia Akademii Umiejętności”. Kraków 2 maja 10 czerwca 1973 r., „Rocznik Biblioteki PAN w Krakowie”, R. 19: 1973, s. 149, 170. 
przyczyną utworzenia tej Fundacji stał się fakt przysłania pisarzowi daru w kwocie 15000 rubli przez nieznanego wielbiciela jego talentu, podpisanego „Michał Wołodyjowski”, a którego nie chciał zatrzymać dla siebie. Postanowił ufundować stypendium administrowane przez Akademię Umiejętności, przyznawane literatom, uczonym i artystom zagrożonym gruźlicą. Z pomocą adwokata Lucjana Wrotnowskiego opracował w piętnastu punktach statut fundacji, przesłany Akademii 11 lutego 1889 r. Zgodnie z jego zapisem, odsetki od kapitału miały być przekazywane jako bezzwrotna zapomoga dla chorych w celu leczenia, a tym zagranicznej kuracji. Decyzję, komu przyznać stypendium (wypłacanego w dwóch ratach) podejmował Henryk Sienkiewicz spośród przedstawionych kandydatur, po jego śmierci - potomek, lub też Zarząd Akademii Umiejętności. Statut, z pewną modyfikacją w $1901 \mathrm{r}$. obowiązywał do końca istnienia Fundacji. Ze stypendium, przyznawanego w latach 1889-1918 korzystali, często wielokrotnie, m.in. Konstanty Mańkowski, Leonard Lepszy, Maria Konopnicka, Stanisław Wyspiański, Gustaw Daniłowski, Wacław Karczewski, Stanisław Witkiewicz, czy Kazimierz Tetmajer. W czasie I wojny światowej nastąpiła przerwa w udzielaniu stypendiów. Fundacja im. śp. Marii z Szetkiewiczów Sienkiewiczowej, ustanowiona przez pisarza, w ciągu 30 lat istnienia wspomogła 17 osób, głównie literatów, kwotą po 1600 koron. Fundacja, niestety, wygasła z powodu dewaluacji papierów wartościowych. Obliczono, iż w 1932 r. odsetki od funduszu wynosiły około $53 \mathrm{zl}$, czyli praktycznie uległ on likwidacji ${ }^{59}$.

Henryk Sienkiewicz 9 maja 1893 r. został zaliczony w poczet czynnych członków zagranicznych Wydziału Filologicznego Akademii ${ }^{60}$. Był wówczas jednym z najwybitniejszych polskich pisarzy, a zamieszkały w Warszawie, a więc w Królestwie Polskim, jako poddany rosyjski, został uznany za członka zagranicznego. Nie bez znaczenia było też zapewne utworzenie wyżej wspomnianej Fundacji zarządzanej przez AU.

W roku 1911 Henryk Sienkiewicz otrzymał Nagrodę im. Mikołaja Reya w wysokości 4100 koron oraz złoty medal. Komitet Akademii Umiejętności nagrodził pisarza za ósme wydanie Ogniem i mieczem, które ukazało się w 1909 r. Uhonorowana też została cała działalność pisarska Sienkiewicza ${ }^{61}$. Rok 1916 przyniósł mu kolejny dowód uznania ze strony Akademii Umiejętności, a mianowicie przyznanie nagrody z funduszu im. śp. Erazma i Anny Jerzmanowskich, wynoszącą 44245 koron, 80 halerzy ${ }^{62}$.

${ }^{59}$ E. Dziurzyńska, Fundacja im. śp. Marii z Szetkiewiczów Sienkiewiczowej w Akademii Umiejętności, „Rocznik Biblioteki PAN w Krakowie”, R. 42: 1997, s. 135-147. Istnieje przypuszczenie, iż pod pseudonimem „Michał Wołodyjowski” ukryła się Maria z Hołowińskich Czosnowska. Zob.: H. Markiewicz, Sienkiewicz Henryk..., s. 207.

${ }^{60}$ Sktad Akademii Umiejętności w Krakowie (w maju 1894 r.), „Rocznik Akademii Umiejętności w Krakowie”, R. 1893/1894, Kraków 1894, s. 10; Członkowie Akademii Umiejętności oraz Polskiej Akademii Umiejętności 1872-1952, oprac. E. H. Nieciowa, Wrocław-Warszawa-Kraków-Gdańsk 1973, s. 115.

${ }^{61}$ Nagrody i konkursy, „Rocznik Akademii Umiejętności w Krakowie”, R. 1910/1911, Kraków 1911, s. 171-172.

${ }^{62}$ Nagrody i konkursy, tamże, R. 1914/1916, Kraków 1916, s. 138. 
Podsumowując ten krótki rejestr pamiątek po Henryku Sienkiewiczu w zbiorach rękopiśmiennych Biblioteki Naukowej PAU i PAN, należy stwierdzić, że nie przedstawiają się imponująco, w porównaniu np. z pamiątkami po Stanisławie Wyspiańskim, pamięci którego poświęcono rok $2007^{63}$. Materiały związane z Sienkiewiczem cieszyły się jednak zainteresowaniem, o czym świadczy chociażby publikacja jego listów. Pozostałe obiekty również były wykorzystywane w różnym zakresie i formie przez badaczy. Warto zatem, z okazji Roku Sienkiewicza, podkreślić, iż pamiątki po wielkim pisarzu znajdują się również w Bibliotece Naukowej PAU i PAN.

\section{EWA DANOWSKA}

HENRYK SIENKIEWICZ'S MEMORABILIA IN THE COLLECTION OF THE SCIENTIFIC LIBRARY OF THE POLISH ACADEMY OF ARTS AND SCIENCES AND THE POLISH

\section{ACADEMY OF SCIENCES IN CRACOW}

\section{Summary}

2016 marks the $170^{\text {th }}$ birthday and $100^{\text {th }}$ death anniversary of Henryk Sienkiewicz. On this occasion The Senate of Poland proclaimed 2016 the year of Sienkiewicz. In the Scientific Library of the Polish Academy of Arts and Sciences and the Polish Academy of Sciences there are a lot of materials connected with the writer, the majority of them studied and published. There are bio- bibliographical materials; especially interesting are his letters to private people and to institutions. A very valuable item is the manuscript of the "Letters from Africa" from the "Czas" (a daily newspaper) files. Sienkiewicz is referred to in the memoirs of Felicja Kęszycka-Schnayder, who describes her meeting with the writer in Switzerland and later his funeral. Sienkiewicz and his work was also the subject of the studies of Józef Marian Święcicki, Benedykt Filipowicz or Józef Tretiak. An example of the writer's interest in fine arts are his pencil drawings- sketches. The Library possesses also numerous photographs of Henryk Sienkiewcz. What is more, in Father Jan Fijałek's collection there are numerous newspaper clips referring to Sienkiewicz giving an insight into his life and work. Sienkiewicz's links with the Academy of Arts and Sciences should also be mentioned. He was a founder of Maria Sienkiewicz née Szetkiewicz (his wife) scholarship that was administrated by the Academy of Arts and Sciences.

${ }^{63}$ B. Sieraczyńska, Pamiatki po Stanisławie Wyspiańskim w zbiorach Biblioteki Naukowej PAU i PAN w Krakowie, „Rocznik Biblioteki Naukowej PAU i PAN w Krakowie”, R. 52: 2007, s. 549-572. 
